\title{
MEMÓRIAS, NARRATIVAS POLÍTICAS E DICOTOMIAS DA CIDADE: OLHARES FÍLMICOS SOBRE RECIFE-PE
}

\author{
Wendell Marcel Alves da Costa ${ }^{1}$
}

\section{Introdução}

O espaço urbano da cidade está representado em diversas realidades cinematográficas. Nos filmes está abordada uma série de questões envolvendo a sociabilidade, a violência das cidades e os processos culturais vigentes na sociedade industrializada. Assim, muitas vezes, os filmes recorrem ao espaço urbano como proposta de dimensionar a construção das personagens, porque justamente esse ambiente comporta heterogeneidade de identidades - e a produção social do espaço surge como possibilidade de compreensão do mundo contemporâneo -, compondo na história um conjunto de ações organizadas e representantes do espaço social vivido.

Aqui, compreendemos o cinema como uma produção humana carregada de ideologia e profundamente requisitada pelo imaginário social do espaço urbano. Essa concepção sustenta-se na idéia de que a instituição social do cinema está inevitavelmente absorta na certeza de que o poder simbólico incidido nas narrativas audiovisuais está em comunicação constante com a construção social da realidade.

Esse pensamento conduz à noção de que o cinema utiliza códigos, convenções e símbolos da realidade para construir o seu próprio espaço narrativo repleto de interações sociais, decodificadas pelos espectadores através da similitude inerente às narrativas audiovisuais e os contextos históricos e culturais apresentados nos filmes. Logo, o cinema mune-se de atributos da realidade e, no processo de produção artística, se distancia dela para construir a sua realidade fílmica, apresentando outra forma de ver as coisas do mundo. Em suma, o audiovisual conduz o mundo, o fabrica ao seu modo por meio da linguagem cinematográfica (Comolli, 2008).

$\mathrm{Na}$ concepção de que o espaço urbano é um arcabouço de representações simbólicas e um campo político sujeito à intervenção constante de agentes sociais no complexo processo de produção do espaço, em seus sentidos particulares de lugar e nãolugaridades (Augé, 2008), a produção audiovisual encarrega-se do desafio de realizar

\footnotetext{
${ }^{1}$ Universidade Federal do Rio Grande do Norte, Brasil.
} 
uma leitura dos meandros circundantes dos fenômenos sociais presentes no âmbito urbano.

Diante desse contexto, destacamos a imagem cinematográfica como um substrato da produção do imaginário social acerca de temas presentes na sociedade contemporânea. As fronteiras conceituais estão cada vez mais imbricadas na discussão acerca das identidades culturais, representações sociais, papéis sociais, empoderamento, produção de discursos e processos culturais. Os sentidos sobre esses paradigmas conduzem a uma narrativa social a respeito dos modelos estabelecidos.

A imagem na contemporaneidade é um elemento que está em sincronia com os desafios trazidos pela quebra ou invisibilidade das fronteiras culturais e simbólicas (Ortega, 2010), além de dificultar a sistematização da experiência específica sobre a sua total influência na realidade social (Jameson, 2004). A imagem, sendo um condutor de ideologias e concepções simbólicas, agencia sujeitos, estigmatiza grupos, agrupa etnias, desloca componentes, produz retóricas mundializadas e discursos dialéticos, forja comportamentos e representa vivências "perfeitas". Em síntese, desconstruir a imagem, principalmente a fílmica, tornou-se um exercício constante no sentido de que existe atualmente um processo constante e globalizado da estetização do mundo (Lipovetsky, 2015).

É, sobretudo devido a esse fato, que existe uma atenção sobre a produção audiovisual do Recife-PE, na tentativa de compreender como são construídos os diferentes olhares fílmicos acerca de um mesmo espaço social e dos seus movimentos sociais. O olhar fílmico dirigido à cidade do Recife precisa levar em consideração que suas imagens também são objetos do olhar (Gomes, 2013), então se torna primordial considerar uma narrativa geográfica visual descolonizada visando sempre o processo de decodificação do imaginário perpetrado na análise da imagem cinematográfica (Shotat e Stam, 2006; Amâncio, 2000).

No cenário da imagem cinematográfica, o cinema pernambucano produz narrativas sobre o espaço urbano (Nogueira, 2009) com o objetivo de gerenciar da forma mais plástica possível os desafios urbanos trazidos pela contemporaneidade. $\mathrm{E}$ analisar essas narrativas é uma forma de identificar as projeções dos contextos históricos e sociais em que esses filmes são criados. 
De forma singular, os curtas-metragens recifenses congregam em seus enredos fatos políticos, sociais e culturais vigentes sobre uma cidade que se tornou com o tempo um dos principais centros de produção cinematográfica do país. A produção cinematográfica de curtas-metragens tem chamado atenção pela qualidade estética dos filmes. As espacialidades e as narrativas dos curtas-metragens documentários pernambucanos contemporâneos situam a cidade do Recife na posição de um olhar sobre as interações sociais, relacionando na narrativa o contexto do processo de subjetivação do espaço utilizado para as histórias documentadas (Costa, 2016a).

Tendo em vista esse painel, os curtas-metragens Pausas Silenciosas (Mariana Lacerda, 2013), Em Trânsito (Marcelo Pedroso, 2014) e A Clave dos Pregões (Pablo Nóbrega, 2015) são exemplos que possibilitam discutir a transformação do espaço urbano do Recife e os processos de sociabilidades por meio das narrativas, em três vertentes, respectivamente: a memória da cidade, as narrativas políticas da cidade e a dicotomia da cidade. Aqui, discutimos as narrativas fílmicas urbanas desses filmes e as representações dos processos de sociabilidades que ocorrem no âmbito da cidade.

\section{Cidade: um conceito antropológico e fílmico}

A cidade pode ser considerada como um complexo fenômeno moderno que origina diferentes modos de operações socioespaciais no campo da sociabilidade entre os sujeitos envolvidos nos processos comunicacionais. A cidade pode ser um ambiente de reconhecimento do espaço (De Certeau, 1998), comunicação e construção de variáveis percepções sobre o espaço arquitetural (Canevacci, 2004), trajetos, composições, significações e operações simbólicas regidas por sociabilidades delimitadas pelo espaço urbano da metrópole (Magnani, 2002; 2008), além de deflagradora de medos, inseguranças e vulnerabilidades sistêmicas no tráfego, ruas, becos e avenidas (Bauman, 2009; Caldeira, 2000).

Trabalhar com a cidade é identificar os arranjos de sociabilidade entre as pessoas nos espaços por onde as comunicações são criadas ou desfeitas. Praças, restaurantes, cinemas, boates, escritórios, prédios residenciais e comerciais, complexos residenciais, aeroportos, terminais rodoviários e estações de trens: todos esses espaços possuem sentidos que flexionam as comunicações na cidade, produzindo assim sociabilidades regidas por estabelecimentos hierarquizados socialmente. Além disso, 
também se têm os espaços "comuns": ruas, avenidas, becos e travessias. Estes últimos, por meio das relações sociais de poder e dos processos comunicacionais são transformados e significados em tipologias como: cantos, trajetos, circuitos, manchas, pedaços e lugares.

Em outras palavras, são as práticas sociais que dão significado e/ou ressignificam os espaços, por meio de uma lógica que se opera em muitos eixos de significação, por exemplo: casa / rua; masculino / feminino; sagrado / profano; público / privado; trabalho / lazer, e assim por diante. Estas categorias dicotômicas congregam sentidos próprios a partir das relações sociais que acontecem nos espaços da cidade, na medida em que as diferenças entre os indivíduos funcionam como um canal por onde, efetivamente, os conflitos acontecem nos espaços "comuns".

Nessa ordem, os espaços "comuns" são entendidos aqui como os locais por onde as comunicações acontecem no âmbito urbano tendo como referência a interação social entre os indivíduos. Eles estão presentes em bairros da periferia da cidade ou em localidades onde as residências são de alto padrão de vida. Por sua vez, os complexos residenciais e os prédios residenciais, por possuírem configurações de sociabilidades diferentes das que ocorrem nos espaços "comuns", uma vez que eles têm segurança e espaços de entretenimento com parques e salas de jogos próprias, efetuam outras linguagens de comunicação na esfera urbana. Assim, tem-se uma imagem da cidade: os espaços "comuns" e os espaços de convivência fechados.

Em princípio, a reestruturação da paisagem urbana prescreve diferentes estados de conviver com outras pessoas. Busca-se a seleção daqueles com quem se deve dialogar diariamente; a intenção é fugir dos sons "comuns" da metrópole, e os espaços de convivência fechados são construídos para este fim. Enquanto isso, os espaços “comuns" estão convertidos na linguagem urbana com os seus sons, cheiros, cores e os problemas sociais como o da violência urbana.

Em acordo com o apresentado, identificamos aqui, também, a cidade como um arcabouço de imaginações, cenários para subjetividades, palco para representações sociais, campo de disputas políticas e simbólicas. A cidade aparece como um dispositivo que representa uma sociedade mutante e industrial, eclética e multicultural, individualista e pragmática (Velho, 2002; 1981) através da intersecção de diferentes modos de operações socioculturais. 
Em suma, a cidade configura-se como um espaço por onde ocorrem subjetivações, ressiginificações e decodificações dos sujeitos com o espaço urbano, aonde as relações sociais ocupam os lugares e dão sentidos específicos a eles. A questão urbana é um objeto em que o antropólogo pode identificar as mudanças ocorridas no espaço urbano da cidade a partir da intervenção e do ajustamento dos atores sociais nas esferas sociais particulares nos lugares da metrópole - mediações, identidades, memórias, trajetórias, projetos e biografias também fazem parte da construção estética e simbólica da cidade (Velho, 2013).

São os sujeitos em seus procedimentos cotidianos, eventos, rituais, associações comunitárias, dissociações simbólicas e deslocamentos nos espaços "comuns" que implicam na identificação das sociabilidades no âmbito urbano. Desse modo, a interpretação parte de um grupo, ou de uma comunidade com as suas pastas políticas e simbólicas e de poder, para então descrever uma leitura geral das questões urbanas.

O antropólogo lida e tem como objetivo de reflexão a maneira como culturas, sociedades e grupos sociais representam, organizam e classificam suas experiências. Neste sentido sua tarefa consiste em captar o arbitrário cultural que define toda e qualquer sociedade [...]. (Velho, 2013: 84).

Cada vez mais, na sociedade moderno-contemporânea, a construção do indivíduo e de sua subjetividade se dá através de pertencimento e participação em múltiplos mundos sociais e níveis de realidade. Assim a viagem pode se dar internamente a uma sociedade específica diferenciada, não significando mais necessariamente um deslocamento geográfico, físico-espacial, mas, sobretudo, um trânsito entre subculturas, mundos sociais, tipos de ethos ou, mesmo, entre papéis sociais do mesmo indivíduo (Velho, 2013: 142).

$\mathrm{Na}$ medida em que a Antropologia Urbana, por meio da etnografia urbana, identifica os sujeitos na sociedade e possibilita compreender as evidências simbólicas do grupo no qual ele está inserido e contextualizado com os seus papéis e funções sociais, uma narrativa social e urbana desse sujeito é construída. Como já nos referimos, as relações de poder estão presentes nos processos comunicacionais e as estratificações sociais dos grupos sociais são condições das relações de poder cultural e econômico dos indivíduos (Bourdieu, 2002; 2007).

O estudo da Antropologia Urbana do espaço urbano da cidade confere um sentido particular na pesquisa qualitativa dos movimentos socioespaciais que ocorrem na cidade contemporânea. Contudo, como o tema da espacialidade da cidade é muito amplo, e as pesquisas antropológicas estão prescrevendo interpretações cada vez mais abrangentes do espaço da cidade - sobre a velhice, as relações de gênero e de 
sexualidades, as corporalidades na cidade, a raça e a multiculturalidade lingüística nos lugares, a política e o poder na construção da paisagem urbana -, um recorte é conveniente na análise das relações sociais nos espaços "comuns".

Os espaços "comuns" são de grande relevância para a compreensão das sociabilidades que acontecem na cidade. Isso porque os espaços são conseqüências das próprias relações sociais - de poder, política, cultural, simbólica, econômica - entre os indivíduos, e eles criam estabelecimentos sociais formados por grupos e/ ou comunidades com os seus códigos particulares. Hipoteticamente, um grupo LGBT em uma praça central da cidade de Belo Horizonte; um grupo de funk no subúrbio da cidade de São Paulo; um grupo de surfistas naturistas na praia de Ponta Negra, em Natal; ou, talvez, uma equipe de estudantes de cinema, no Movimento Ocupe Estelita, na cidade do Recife; até o exemplo de skatistas que fazem diariamente manobras em uma estação de trem desativada, em Fortaleza, representam-se a partir do estabelecimento de códigos próprios à ordem do escopo urbano das cidades.

Esses grupos provocam a mudança significante do espaço "comum" da cidade. Os grupos, com as suas identidades culturais, através de suas interações, diálogos, práticas e dos seus gostos e desejos, dão um sentido aos lugares da praça ou da estação de trem desativada, por exemplo. O lugar poderia não ter tido uma significação simbólica antes das práticas nelas existentes. Ele seria considerado neutro ou destituído da imagem de um espaço praticado ou espacializado socialmente pelos sujeitos.

Diante desse contexto, o olhar antropológico sobre o espaço urbano da cidade admite as práticas sociais no espaço em que ocorrem as relações sociais e de poder. No âmbito fílmico, sob o olhar do gênero documentário - e de um possível processo de hibridização das narrativas -, podem ser discutidas essas relações sociais na cidade no sentido de (des)construir e analisar as representações fílmicas das sociabilidades.

Assim, as relações entre cidades, memórias e identidades podem ser significantes quando se leva em consideração que, "na maior parte das vezes, a nossa percepção da cidade não é íntegra, mas sim bastante parcial, fragmentária, envolvida noutras referências. Quase todos os sentidos estão envolvidos e a imagem é o composto resultante de todos eles" (Lynch, 1960: 12). A cidade no cinema prioriza a concatenação de códigos específicos orientadores de uma mensagem que tem como conteúdo a especificidade espacial e social do espaço urbano e da sua arquitetura no cinema (Barber, 2002; Bruno, 2002). 
A prática de documentar a cidade provoca uma reflexão sobre as diferentes referências históricas, simbólicas e artísticas relacionadas a fenômenos políticos, econômicos ou espaciais da cidade. Com relação a esse fato, no gênero documentário desenvolvem-se narrativas que possibilitam mesclar as perspectivas acerca de um determinado tema contextualizado em tempos e espaços específicos. O olhar fílmico sobre a cidade, nesse caso, é uma perspectiva por meio do qual o indivíduo que "assiste" a cidade, também distribui sentidos afetivos ao espaço urbano de convivência durante a produção de um filme, podendo realçar determinadas sensações dela.

Destaca-se, também, a diferenciação entre o "olhar", o "ver" e o "assistir" a cidade, quando essas posições de observação influenciam diretamente os modos como subjetivamos e identificamos a cidade por uma perspectiva, seja ela geográfica e/ou cartográfica, sonora e/ou estética. Não podemos negar também que uma posição da perspectiva do observar está sempre presente: a espacial, com a identificação dos objetos, indivíduos, cantos, ângulos que cortam os lugares e os ritmos uniformes da cidade. Assim, documentar a cidade tem em vista elaborar um discurso primeiramente da posição do observar um ambiente (a cidade) e as ações materiais e imateriais de valores simbólicos que são apreendidos pelo cinema.

De acordo com Campo (2015: 5),

É necessário entender o cinema documentário, [...] como aquele que faz uso de documentos audiovisuais para reconfigurá-los de acordo a parâmetros estéticos cinematográficos que superam o nível de registro da realidade. Isto é, em uma imagem, e também na construção dos sons, não só funcionam como um registro do real como também ordenam, modificam temporal e espacialmente, fragmentam e modificam os eventos; em suma, elaboram discursos (tradução nossa) ${ }^{2}$.

Com efeito, a prática de documentar a cidade desperta também reflexões de cunho filosófico e existencialista na construção do espaço urbano como um ambiente por onde inúmeros acontecimentos encontram palco para que os indivíduos em seus eventos diários possam representar papéis em locais que são superintendidos por lógicas comumente estruturadas pelas relações de poder. Essas relações de poder, que se ajustam no âmbito urbano, carregam representações da sociedade estruturadas nas classes sociais oriundas da formação histórica e cultural do lugar da cidade, perfazendo em si própria os conflitos e as associações arraigadas pelas categorias de dominação no contexto sociopolítico do país.

\footnotetext{
${ }^{2}$ Todas as traduções dos textos foram feitas pelo autor deste trabalho.
} 
No rompante de documentar a sociedade e a cidade através da imagem cinematográfica, os cineastas constroem um discurso ideológico e simbólico imputado nas relações sociais da cidade. Dificilmente, no gênero documentário, os filmes se esquivam dos temas ligados a esses assuntos que, de tão sobrepostos na conjuntura atual política do Brasil, encontram um profícuo lócus de discussão nos meios de comunicação em massa. Alguns desses temas são a desigualdade e estratificação social, a intensificação da especulação imobiliária, a "perda" da memória e da identidade da cidade.

Enquanto linguagem que identifica uma determinada situação social, os filmes documentários propõem um debate político visando a colaboração de diferentes discursos na construção da história a ser contada. O documentário é, em essência, um dos gêneros cinematográficos que situa o teor político dos fatos que retrata de uma forma eminentemente singular, organizando discursos, incitando os elementos que constituem o enredo nas dimensões que são equivalentes em uma boa história: perscrutar um tema na história e, ao mesmo tempo, indagá-lo através de diferentes pontos de vista, ou também, a partir de um olhar nunca antes visto, colaborando assim com a construção dialética do tema.

Com outras palavras, o documentário:

\begin{abstract}
Merece a nossa atenção, não porque é mais verdadeiro que a ficção, ou melhor documento, mas porque testemunha sobre uma sequência vivida anteriormente. A esta sequência, pode-se destacá-la, pulverizá-la, fazê-la participar de um discurso que conduz à progressão, negar sua singularidade para atuar unicamente sobre sua capacidade metafórica (Gauthier, 2013: 6-7).

Tem sido um dos principais canais do discurso e da retórica política e que, por outra parte, tem uma porcentagem significativa de filmes documentais que tem apresentado conceitos, problemáticas e posturas políticas de forma mais ou menos sutil (Campo, 2015: 15).
\end{abstract}

A cidade e os seus movimentos socioespaciais estão intimamente ligados às afetividades dos sujeitos no espaço urbano, sendo esse espaço um território propício na investigação pelo documentário. Desde as primeiras produções do gênero, o documentário manteve as relações entre as pessoas como fundamentalmente provocadoras quando alocadas no âmbito da cidade moderna, que trazia em si as suas novas configurações sociais destacadas no contexto político da época. Nesse período, certos filmes podem ser notáveis quando o assunto é construir a cidade a partir de um 
olhar e de uma técnica diferenciados, como no filme Um Homem com uma Câmera (Dziga Vertov, 1929).

Anteriormente, documentar a cidade não levava em conta o uso de técnicas de filmagem elaboradas, até por que o cinema ainda não havia se tornado uma arte propriamente dita, ou seja, com uma linguagem própria. Como exemplo, os curtos filmes dos franceses Auguste e Louis Lumière se preocupavam em registrar objetivamente os espaços da cidade e a ação dos indivíduos. Contudo, é percebida também nesses filmes a necessidade de posicionar a câmera em ambientes de profunda importância espacial, por isso, indica-se dois dos seus filmes e os locais onde são filmados para exemplificar sobre a documentação da cidade: uma estação de trem e a frente de uma fábrica. O primeiro espaço representa um local onde as pessoas estão em movimento, e são controladas pelo tempo que as impede de parar e, por conseguinte, dificultando a movimentação dos outros transeuntes. O segundo exemplo de espaço, a fachada de uma fábrica, mostra a saída de alguns operários de uma empresa industrial, representando novamente o movimento característico da cidade moderna.

Em vista desses exemplos, a cidade é imaginada pela necessidade constante e coercitiva do movimento, gerando em conseqüência a isso uma necessidade pelo aproveitamento ou desperdício do tempo e sempre almejando, se não a transformação, mas a mudança constante das coisas ao redor. Essa mudança não está relacionada às estruturas presentes na recente sociedade de classes da época, mas sim à ocupação progressiva dos espaços da cidade por meio das pessoas e assim por diante; o exemplo da estação de trem demarca o fenômeno do qual estamos falando a respeito do movimento das pessoas na cidade.

Documentar a cidade e os seus movimentos - de pessoas, objetos, veículos -, que são perpendiculares à constituição social do espaço urbano, também ressignifica o espaço que está sendo representado. No momento da ressignificação, é construída outra leitura daquela organização espacial filmada, porque justamente no momento da filmagem ocorre a transformação conceitual e simbólica do que é registrado pela câmera cinematográfica. Nessa ótica, destacamos que os dois exemplos de espaços filmados pelos irmãos Lumières reproduzem um imaginário sobre os dois lugares da cidade que são, para ambos os cineastas franceses, espaços significantes e que possuem uma sensível significação para a sociedade de sua época. Em nossa leitura, a constância de filmar espaços “comuns" nas obras dos Lumières, não apenas identificam locais que são 
visualizados por eles, como criam possibilidades representacionais de passeio pelos indivíduos, como na sequência filmada da estação de trem.

A imagem que primeiro documentou o espaço da estação de trem, no mesmo instante que a representa, também produziu um efeito conceitual através da filmagem. Em suma, o ato de filmar um determinado espaço da cidade, seja ele uma praça na periferia, uma estação de trem, uma rua movimentada ou um edifício em construção, produz uma ficcionalização daquilo que é gravado pela lente da câmera cinematográfica. Em outras palavras, possibilita criar um conceito fílmico da imagem da cidade.

É essencial levar em consideração que a imagem cinematográfica não é uma reprodução da realidade. É um simples gesto de eleger o que se quer registrar, definir uma abordagem estética e narrativa são fatores que estabelecem um elemento de "representação" e "criação". Por detrás de sua objetividade, a imagem cinematográfica nasce subjetiva (Valles, 2015: 57).

O cinema não deve se alimentar dessa espacialidade "real" com o intuito de garantir o seu funcionamento e verossimilhança, mas usufruir e submeter essa espacialidade à suas recriações e subverter suas dinâmicas e contigüidades tornando-as novas e múltiplas (Neves, 2010: 150).

O termo ficcionalizar a cidade quer dizer realizar uma leitura conceitual sobre o espaço urbano por intermédio da imagem cinematográfica. Como citado, a câmera cinematográfica transforma o objeto filmado em qualquer outra coisa que nunca antes o foi. Ademais, a cidade, que está em constante movimento - pessoas, carros, trens e ônibus -, é ficcionalizada pela imagem cinematográfica que perscruta em sua lente os códigos, símbolos, representações e imaginários, construindo assim outro espaço.

O movimento da câmera cinematográfica que acompanha o movimento das personagens em cena conduz as narrativas a uma realidade que não é necessariamente fiel ao que está sendo filmado. Algumas propostas fílmicas são as de tornar fidedigna a imagem produzida da realidade social, porém o movimento da câmera suscita a construção de novos códigos e concretiza a representação cinematográfica. Em resumo, o movimento da câmera "fornece um denso fluxo de informações sobre os objetos inclinados, suas bordas, seus cantos, suas superfícies, as suas relações com os outros objetos" (Bordwell, 1991: 233).

O cinema de não-ficção no Brasil, assim como em outras produções nacionais, possui componentes de outros gêneros que não sejam do documentário. Nesses filmes fica a incógnita sobre qual o gênero do filme. A partir do momento em que a câmera é 
posicionada em determinado eixo ou no processo da própria edição do material, a dita "realidade" não resiste, sendo alterada para um documento artisticamente pessoal, visto que as "intervenções e decisões criativas do cineasta e demais envolvidos no processo de produção" (Costa, 2014: 167) são inevitáveis.

Um documentário que pretenda retratar a realidade sofre uma modificação como todas as notáveis formas de plasticizar a vida. $O$ que se filma, portanto, é transformado em qualquer outra coisa por meio do como se filma. Só o ato de filmar, em suma, já modifica a noção da realidade, da coisa categoricamente única e imutável.

Nesse hiato, vamos tomar um exemplo da Antropologia Visual considerado hoje como uma das produções pioneiras do documentário mundial, o filme Nanooke, o Esquimó (Robert J. Flaherty, 1922). Apesar de ser considerada uma obra do gênero documentário, o filme coopera na discussão elementar da representação dos personagens. Os personagens/atores estão encenando com didatismo para o diretor como é a vida dos esquimós em uma região do planeta, mostrando o comportamento e a relações de vida dessas pessoas num ambiente diferente da cidade moderna daquele tempo. Estão representando papéis em um espaço que é, por excelência, um palco para que atores sociais encenem as ações diárias do esquimó: a caça, a família e as migrações sazonais.

Isto nos leva, sobre a ficcionalização da imagem, a entender como que as corporalidades fílmicas ${ }^{3}$ são construídas pelos personagens no momento da filmagem. A corporalidade fílmica é o alicerce para que o discurso do filme possibilite revelar os sentidos que são importantes para a história: no plano do filme os corpos dos personagens são deslocados na cena, gerando ação e modificação do espaço encenado. Nessa locomoção dos corpos no espaço fílmico uma corporalidade fílmica dos personagens apresenta-se, acarretando numa construção simbólica, espacial e subjetiva.

A posteriori, sabemos que a origem antropológica do documentário é a preocupação com as transformações culturais, desde a realidade social retratada na metalinguagem de Vertov, até aos filmes cínicos, porém de linguagem inovadora, de

\footnotetext{
${ }^{3}$ As corporalidades fílmicas são o resultado do jogo cênico de representação regado no contexto do espaço fílmico contemporâneo. Como se sabe, os corpos quando inseridos em um determinado espaço observado por outros sujeitos, isso inclui o dispositivo mecânico da câmera cinematográfica, transformam-se em corporalidades fílmicas próprias do espaço fílmico de representação simbólica. Para Xavier (2015: 229), "dentro desta dinâmica de relações pautada pelo fetiche da imagem como certificado de existência, ter uma câmera apontada para si tornou-se um 'privilégio ontológico' gerador de uma ansiedade exibicionista. Impôs-se o 'efeito câmera' como elemento que estrutura certas situações em que é inevitável a teatralidade, o pequeno (ou grande) jogo social onde cada qual assume um papel - ou imagem - dentro de novas modalidades de convívio geradas pelo olhar dos aparelhos".
} 
Jean Rouch. Os interesses dos antropólogos cineastas contemporâneos perpassam a linguagem visual que, anteriormente, só serviam para documentar a composição social de um grupo étnico em uma dada população primitiva no século XIX.

Com destaque, as narrativas dos documentaristas antropólogos interpelaram o Outro com maior entusiasmo e inovação do que os seus antecessores, dando margem a novas aparências para a linguagem do documentário e dos seus efeitos catalisadores provocados na imagem cinematográfica. Antropólogos como Malinowski e LéviStrauss utilizaram de fotografias e de algumas filmagens em suas pesquisas de campo com os povos primitivos (Alves e Samain, 2004). Mas é com a contribuição de dois etnógrafos visuais, Bateson (técnica do "olho do antropólogo") e Mead (técnica do "olho espião"), e os seus filmes de cunho estruturalmente imersivo e representativo (Barbosa e Cunha, 2006) que a Antropologia Visual se insere no campo da linguagem cinematográfica.

Sem dúvida, o que se percebe são os movimentos estéticos pelos quais o documentário passou no decorrer do século XX. No repertório de sua produção, os cineastas se voltaram para os locais pouco conhecidos do planeta e em seguida também olharam para paradigmas presentes na realidade social das cidades.

Essa "passagem do olhar" foi o que diferenciou o documentar do investigar simbolicamente as nuances das cidades modernas: o escopo do cinema que os irmãos Lumières antes faziam dava espaço agora para uma linguagem politizada com as coisas do mundo, e essa transição reflete efetivamente o propósito de documentar, do que entendemos aqui como filmar - logo, ficcionalizar - ou estetizar os fenômenos sociais a partir de uma posição e de um olhar.

O olhar sobre um fenômeno social, ou uma organização espacial despoja inicialmente outros olhares sobre a cidade, pois a posição na qual o sujeito que olha está situado, pode categorizar desigualmente os sentidos daquilo que se olha. Podemos situar o olhar de muitas maneiras na cena da cidade contemporânea: como objetos ativos ou passivos nos processos de mudanças socioespaciais, sonoras, simbólicas e/ou artísticas dos muros, dos prédios, das ruas e da arquitetura de uma metrópole.

A priori, indagamos: como se olha a cidade, sendo esta, hoje, um ambiente de transações multiculturais, contratos sociais regidos por comunicações contidas em códigos lingüísticos múltiplos construídos por pessoas do mundo todo? Como, enfim, encontrar o lugar do olhar na produção de filmes que percebem a cidade do Recife 
através de uma ótica política, geográfica, filosófica e antropológica em seus diferentes cantos, trajetos, ruas, traçados e becos, às vezes pouco iluminados, organizados e/ou estruturados urbanisticamente?

A diferença entre olhar e ver consiste, portanto, no fato de que o olhar dirige o foco e os ângulos de visão, constrói um campo visual; ver significa conferir atenção, notar, perceber, individualizar coisas dentro desse grande campo visual construído pelo olhar (Gomes, 2013: 32).

Nesse momento, na discussão levantada da análise da diferença entre o documentar - um primeiro momento da filmagem - e o ficcionalizar - um segundo momento da filmagem que é a representação pela imagem -, identificamos duas visões na produção de filmes que se apresentam a partir de um olhar da cidade e dos seus problemas atuais sobre as sociabilidades entre os indivíduos nos processos comunicacionais.

Enquanto que os filmes dos irmãos Lumières viam um objeto a partir da lente, que naquele momento parecia ser um simples jogo visual de entretenimento - e também do sonho e da indiferença de que se tornaria algum dia Arte -, os filmes, por exemplo, de Vertov e Rouch, olharam a cidade na posição de um campo visual por onde significados e representações de suas sociedades estariam presentes no discurso cinematográfico.

Como dissemos, documentar e ficcionalizar aquilo que é filmado fazem parte do mesmo processo de produção de significação dos fenômenos da sociedade, na medida em que a imagem aprisiona os códigos e os elementos do imaginário urbano na chapa audiovisual. E aqui defendemos a noção de que a imagem do cinema tem maior contato com a corrente do realismo de produção do real no cinema do que pelo naturalismo que, ao contrário do que pensamos, é a realidade tal como posta na sociedade (Gomes, 2013).

O olhar para a cidade e a sua corrente manifestação originada na construção do imaginário urbano é o efeito do exercício narrativo. As narrativas cinematográficas, que são o meio pelo qual o cineasta refina a imagem cinematográfica, também são as estruturas nas quais os códigos estão inseridos no contexto fílmico. Eleger as estruturas de enunciação nas narrativas é também conceber o canal pelo qual o discurso fílmico encontrará a atenção do espectador durante a projeção do filme nos espaços de exibição. 
A narratologia oferece ferramentas de análises idôneas para abordar as novas formas que estão adquirindo o cinema documental contemporâneo, e em especial sua exploração das diversas formas de enunciação. É dizer, sobre o que recai o peso da narração, que se esconde nas diversas instâncias enunciadoras que surgem das múltiplas combinações possíveis (Vallejo, 2013: 9).

Certamente, as narrativas audiovisuais se nutrem de um discurso sobre um tema da sociedade. O hibridismo de gênero aparece nos filmes invocando sensações distintas nas narrativas fílmicas, no passo em que a linguagem do cinema - tanto no gênero documentário como no gênero de ficção - se apropria dos lugares da cidade e constroem na imagem cinematográfica, uma estetização desses espaços que em sua origem podem ter um efeito diferente daquele representado pelo filme.

Por analogia, A Cidade é uma Só? (2012) e Branco Sai, Preto Fica (2015), ambos os filmes do cineasta brasileiro Adirley Queirós, são produções que mesclam em suas narrativas o documentário e a ficção para contar as memórias de uma cidadesatélite de Brasília, Ceilândia-DF. Nos argumentos dos filmes, duas realidades temporais se fundem na narrativa de Branco Sai, Preto Fica, enquanto que em A Cidade é uma Só? o ambiente comporta duas histórias que se apropriam das vertentes históricas e simbólicas que convergem ambas para uma concepção geral: os processos espaciais que possibilitaram o surgimento de Ceilândia (Costa, 2016b).

Narrar a cidade é conceber uma imagem desta nas estruturas do contexto espacial do filme. A passagem estético-espacial da cidade para a cidade fílmica requer a estruturação dos códigos e símbolos de poder que preexistem na realidade social, e as narrativas de cinema são os movimentos técnicos que dão potência a essas estruturas dispostas na imagem cinematográfica. De outro modo, a comunicação entre os elementos fílmicos não surtiriam efeito no espectador, decorrendo num ruído que delimitaria a relação paradoxal entre o filme e aquele que o assiste, o sujeito que é passivo na recepção dos códigos, mas que se torna ativo na ressignificação desses pelo inconsciente.

Em síntese, a imagem do cinema é resultado de um sistema de representação incluída em categorias predominantemente sobrepostas nos meandros da construção social da realidade. Diante disso, é necessário investigar os modelos de representação e da construção do imaginário urbano presentes na cidade fílmica do Recife e de como as sociabilidades no espaço urbano da cidade, nas diferentes vertentes políticas, simbólicas, sonoras e estéticas, estão postas na imagem cinematográfica dos curtasmetragens pernambucanos contemporâneos. 


\section{Memórias de uma cidade que não existe mais...}

Pausas Silenciosas é um documentário de curta-metragem que trata de um personagem central da fotografia pernambucana, o fotógrafo Alcir Lacerda. A proposta do filme é realizar uma observação da transformação da paisagem do Recife através das fotografias feitas por Alcir e, ao mesmo tempo, trabalhar o processo de transformação da identidade da cidade do Recife e da memória do personagem-fotógrafo. O fio condutor desta história é o evento marcante da derrubada da Igreja dos Martírios (17911973), na região central da cidade, para dar lugar a um estacionamento de carros.

Este evento da derrubada de uma igreja, tão marcante para a história e para a população da cidade, demarca um processo que está sendo realizado desde a década de 1960 no Recife, que é a reestruturação do seu espaço urbano, que visa à construção desenfreada de edifícios residenciais e comerciais no lugar das casas de moradia e de edifícios que possuem um valor histórico para a cultura da cidade. Este processo, no filme, está contido no registro das fotografias de Alcir, um sujeito que observou a cidade em várias perspectivas de fluxos, dinâmicas, sentidos, e nas dimensões sociais e simbólicas dos espaços dos lugares.

Nesse contexto, a memória afetiva e a perda da identidade do Recife ganha ênfase na metaforização do esquecimento do fotógrafo que registrou os dias movimentados e as noites festivas da capital pernambucana. Nesse painel geral, o fluxo do tempo representado aqui pelo uso da fotografia tem uma potencialidade na interpretação das mudanças trazidas pela contemporaneidade, na medida em que as identidades, os espaços, as relações sociais e a arquitetura da cidade sofrem, cada vez mais, mudanças estruturais.

A fotografia tem a dimensão simbólica de tornar estática uma lembrança. As memórias e as lembranças de um determinado evento social trazem consigo afetividades sejam das pessoas ou do lugar do evento registrado. Fotografar um lugar específico da infância, como um parque ou uma praça, significa representar aquele espaço através da incorporação de elementos que envolvem as emoções e a potência transformadora do tempo sob o presente, apresentando o passado como um momento longínquo, distante e distanciado, mas presenciado pelas pessoas do presente. 
No aspecto do tempo, ele funciona como um elemento de ressignificação dos acontecimentos atribuídos às pessoas e aos espaços. A representação dos espaços de uma cidade por meio da fotografia permite identificar como os sujeitos imaginam os espaços da cidade, sobretudo porque as formas como as fotografias apresentam um momento particular de suas histórias diz muito sobre como é percebido o mundo a sua volta. Sendo assim, sabemos que a fotografia representa um momento da história e que também contribui na construção de um imaginário social sobre os comportamentos das pessoas nos lugares das cidades.

Em Pausas Silenciosas, a narrativa destaca o registro, através das fotografias, da transformação da cidade do Recife, através das lentes de Alcir, que o filme nos apresenta como um sujeito que está em processo de perda da memória. A memória da cidade recifense está não só presente nas fotografias de Alcir; ela está igualmente na memória do próprio fotógrafo, um agente social que conviveu com amigos e familiares nos lugares que registrou. Dessa forma, o filme metaforiza a relação entre a perda da memória e da identidade do Recife e do fotógrafo-personagem Alcir.

A etnografia fotográfica feita por Alcir das praças, avenidas, parques e prédios da cidade que está passando por uma transformação da paisagem nas décadas de 1970 e 1980 registra os lugares de uma cidade que não existe mais. Em outra leitura, uma cidade que possuía trajetórias de pessoas e o movimento específico do centro da cidade ou na região do Recife Antigo antes da modificação da sua paisagem (Figura 1). As fotografias revelam o movimento constante das pessoas e dos carros à noite; dos usos das praças e dos parques dos bairros; os passeios aos cinemas e hotéis, bares e restaurantes: toda uma prática social que era pertencente à identidade cultural e simbólica do Recife.

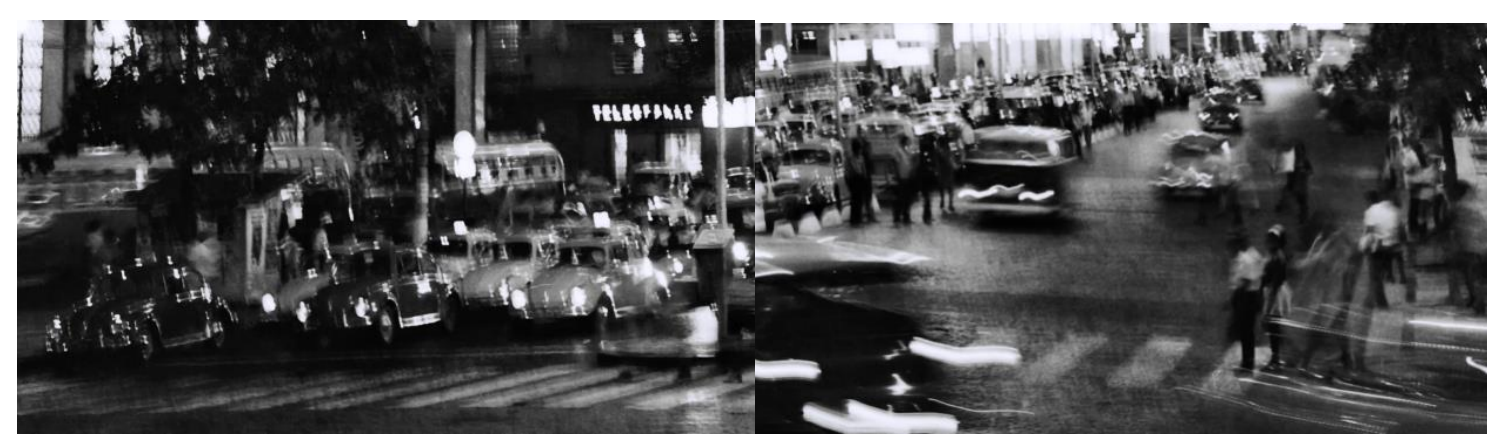

Figura 1 
Em contraposição, os fluxos e os movimentos da cidade dão lugar a um sentimento de nostalgia com a reestruturação da paisagem urbana. Advindas da reestruturação da paisagem urbana, as relações sociais no âmbito da cidade também são transformadas, principalmente com a inserção de tecnologias de comunicação contemporâneas.

As sociabilidades na cidade estão traduzidas noutras linguagens de comunicação na contemporaneidade. A construção simbólica da paisagem urbana pela reestruturação proporcionada pela especulação imobiliária do Recife, nas fotografias feitas por Alcir Lacerda, realça as diferenças das estéticas arquitetônicas, dos desenhos das ruas, das silhuetas da Avenida de Boa Viagem, de outras avenidas em um plano geral em relação à Recife atual, esta representada no curta-metragem com um sentimento de efemeridade dos espaços e das fragilidades das relações entre as pessoas.

O olhar antropológico de Alcir sobre a cidade do Recife não é um olhar sobre o que é diferente; acredita-se que não houve um estranhamento dos espaços e das práticas existentes na cidade. É por isso que, a contento, a dimensão de afetação pela realidade social e espacial do Recife está presente no trabalho do fotógrafo. Todavia, este trabalho de registro fotográfico revela, como já foi dito, uma perspectiva do lugar, um sentimento de efemeridade incorporada no discurso das fotografias essencializado pelo tempo.

Enquanto que o curta-metragem constrói uma posição de olhar essas dinâmicas relacionadas às mudanças trazidas pela contemporaneidade, também afirma, no discurso fílmico, a fotografia como uma memória do mundo. O filme, no exemplo aqui analisado, que é, por essência, um registro da realidade social na falsa sensação de movimento da imagem, preocupa-se com a linguagem que deu acesso à imagem cinematográfica, a fotografia.

Essa discussão estética e histórica das contribuições da fotografia e do cinema não é recente, mas o debate sobre a conjuntura em que se inserem as práticas artísticas dessas duas formas de expressão humana que se modificam e se aperfeiçoam diante dos contextos sociais tem se aproximado da posição do olhar do indivíduo - quer seja o indivíduo um etnógrafo da imagem ou não - sob o seu lugar de convivência.

A figura 2 destaca a paisagem da cidade numa perspectiva do desenvolvimento do olhar sob a transformação do espaço urbano. Nestas fotografias, que possuem uma significância relacionada à construção simbólica da paisagem da cidade, no processo de 
edição do curta-metragem estão presentes códigos para o entendimento da narrativa fílmica: "a passagem do olhar" se transforma aqui na "observação do olhar". Em outras palavras, podemos frisar que nas fotografias apresentadas em Pausas Silenciosas, num primeiro momento, espera-se do espectador a "observação do olhar" da posição do olhar do fotógrafo Alcir. E, num segundo momento, a interpretação dos elementos do imaginário urbano e da representação de uma identidade da cidade que estão contidos nesta posição do olhar do fotógrafo.

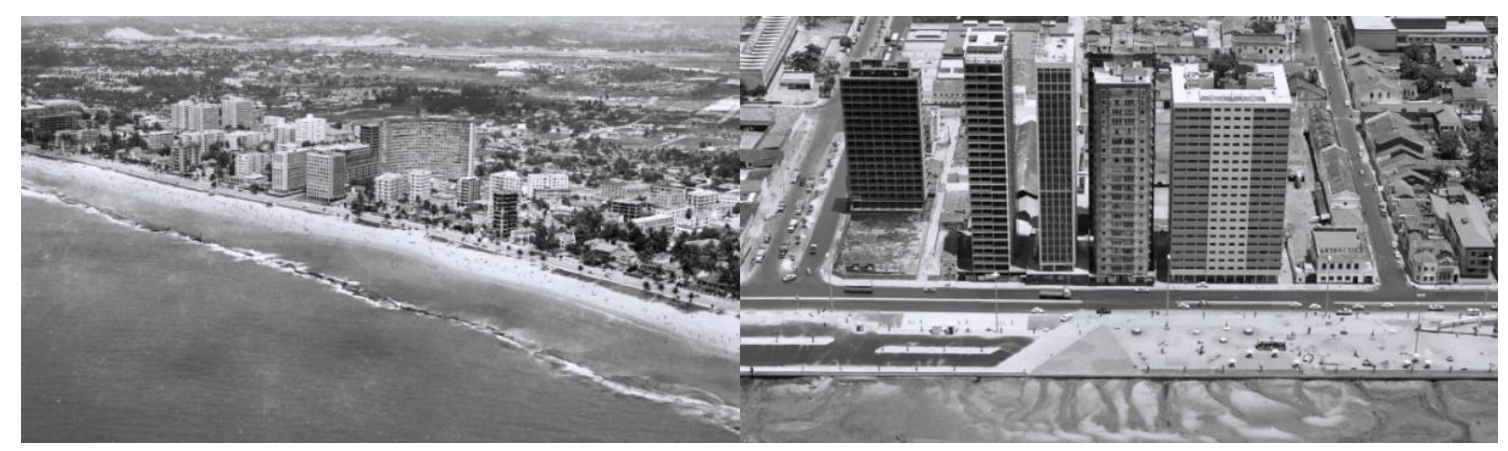

Figura 2

Nesse ínterim, o olhar distribuído nas fotografias do Recife é de preocupação com o espaço arquitetural e com as transformações nos espaços comuns. Sobretudo dos espaços comuns, que são ambientes reconhecidos como de lazer, divertimento de crianças, encontros de jovens, práticas sociais e representação de papéis sociais. Pausas Silenciosas, utilizando do espaço-tempo na contraposição das fotografias do Recife antigo e do Recife atual, produz uma imagem da cidade contemporânea mutante e industrial, individualista e pragmática onde os lugares e as sociabilidades neles acontecem diferentemente (Figura 3).

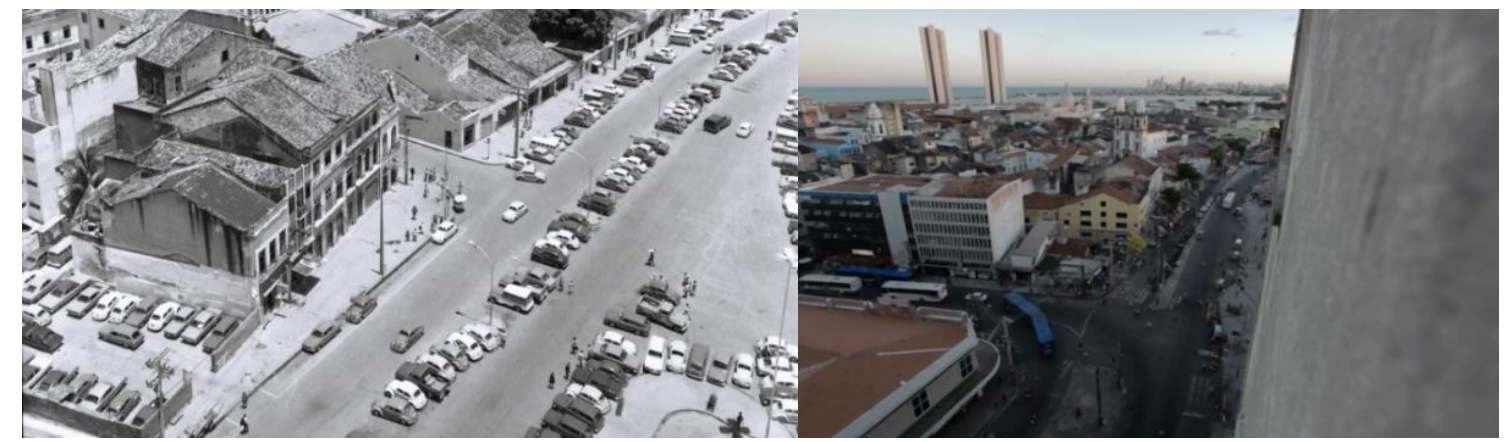

Figura 3 
Os sentidos dos espaços de convivência são construídos na prática social das pessoas nos lugares da cidade. Estes sentidos sofrem modificações simbólicas a partir das transformações do espaço urbano. Um lugar que antes era considerado como ponto de encontro, ou uma região considerada de grande valor simbólico para um grupo social, na transformação do espaço urbano preconiza uma transição ou ruptura das dinâmicas e processos existentes no lugar. Perde-se, enfim, o sentido do lugar em suas dimensões subjetivas não só relacionadas ao espaço, como também aos indivíduos que ali praticam contratos, ações, trocas e que ressignificam rituais e processos sociais dentro das lógicas particulares de cada grupo.

Neste sentido, Pausas Silenciosas identifica, no fluxo do tempo, as mudanças arquiteturais, simbólicas, sociais e identitárias de uma Recife que não existe mais nas fotografias. Nota-se, portanto, uma vinculação direta com o aspecto da memória da cidade, esta sendo representada cada vez mais em produções de curtas e longasmetragens, dando margem aos processos de sociabilidade incorporados nos filmes que trabalham o Recife por uma perspectiva antropológica.

\section{Sinfonias políticas da cidade}

Em Trânsito trata da reestruturação do espaço urbano da cidade do Recife e as questões políticas e de poder que fazem parte do seu entorno. O curta-metragem pressupõe que o jogo político existente no processo de reestruturação do espaço urbano tem relação direta com a estratificação social mantenedora das classes sociais no Brasil, difundida pela indústria automobilística e pela especulação imobiliária.

Neste filme uma narrativa política da cidade é construída, evocando as diferentes dimensões simbólicas, econômicas, sociais e da reestruturação do espaço urbano de uma cidade que perde, paulatinamente, a sua memória e a sua identidade. Este curta-metragem pernambucano, a partir de uma narrativa híbrida, situa a problemática da reestruturação do espaço urbano na justificativa da gentrificação, da desapropriação forçada do espaço e do fortalecimento da desigualdade social no entendimento de que a produção social do espaço urbano repercute o conflito e a diferenciação das classes sociais. 
O espaço urbano da cidade é um campo político onde a luta de classes sociais, no Brasil, encontra o cenário para a sua representação. A própria produção social do espaço urbano da cidade é conseqüência dos tratamentos das relações sociais e dos processos de sociabilidade entre os indivíduos, que são estes, objetivamente, os agentes que dão sentidos particulares aos lugares. Contudo, no cenário da luta de classes sociais as dinâmicas de produção social do espaço acontecem de outras formas, pois a interferência do capital econômico é uma ferramenta de diferenciação e de legitimação das práticas sociais num determinado espaço. Ou seja, tem-se uma cidade apartada, e a gentrificação - processo que articula fatores socioeconômicos -, como apresentado no curta-metragem Em Trânsito, é uma das suas maiores conseqüências sociais.

Inicialmente, o filme constrói uma narrativa política sobre a cidade, e uma narrativa híbrida do espaço urbano, para justamente qualificar a intenção aqui proposta: a ordem do discurso social da especulação imobiliária atinge até o mais indiferente indivíduo frente à reestruturação do espaço urbano. Esse discurso social sobre o projeto da especulação imobiliária pode ser identificado nos enquadramentos da paisagem da cidade, na construção de uma montagem que produz uma teatralidade regida por uma sinfonia política da cidade (Figura 4).

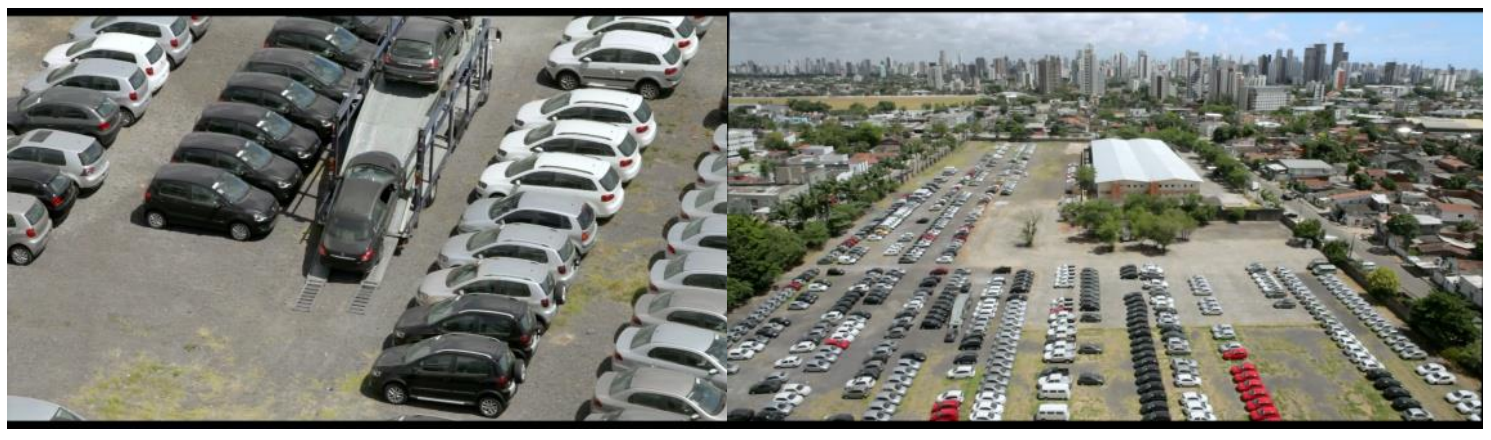

Figura 4

Este curta-metragem qualifica-se em uma narrativa híbrida porque, segundo as discussões já realizadas sobre a ficcionalização da imagem, existem cenas que acontecem em cenários reais: como no tráfego e em locais de construção civil. Um personagem fictício cruza o Recife, observando as mudanças que ocorrem na mobilidade urbana da cidade. Hibridiza-se, portanto, uma questão social com um personagem fictício que representa o processo de gentrificação, que é consequiência do processo de reestruturação do espaço urbano da cidade (Figura 5). 
A interação social que se tem neste exemplo cinematográfico é o conflito entre o indivíduo que sofreu gentrificação - representado aqui por um personagem que mora em uma casa improvisada - frente à indústria imobiliária e automobilística que controla e usa o seu poder de persuasão sobre os indivíduos. O jogo de poder e de controle é muito forte na dinâmica da reestruturação do espaço urbano do Recife, pois os imensos prédios enquadrados pelo filme parecem destituir toda e qualquer manifestação democrática de contrariedade aos projetos da especulação imobiliária. A luta de classes se dá no jogo simbólico, na representação das contradições dos códigos ressignificados por este projeto da verticalização da cidade.

O conflito da luta de classes sociais colocado por Em Trânsito envolve a dimensão política do contato entre eleitor e candidato. As políticas de governo de candidatos, na crítica da figura do político pernambucano Eduardo Campos, deflagram a paisagem cultural da cidade ao mesmo tempo em que produzem a transformação do espaço urbano. Também se incorpora a essa ideologia o incentivo do setor automobilístico que, enquanto potência industrial motora de parte da economia nacional, influencia o modo de locomoção da população e da modificação do espaço da cidade para dar lugar aos veículos.

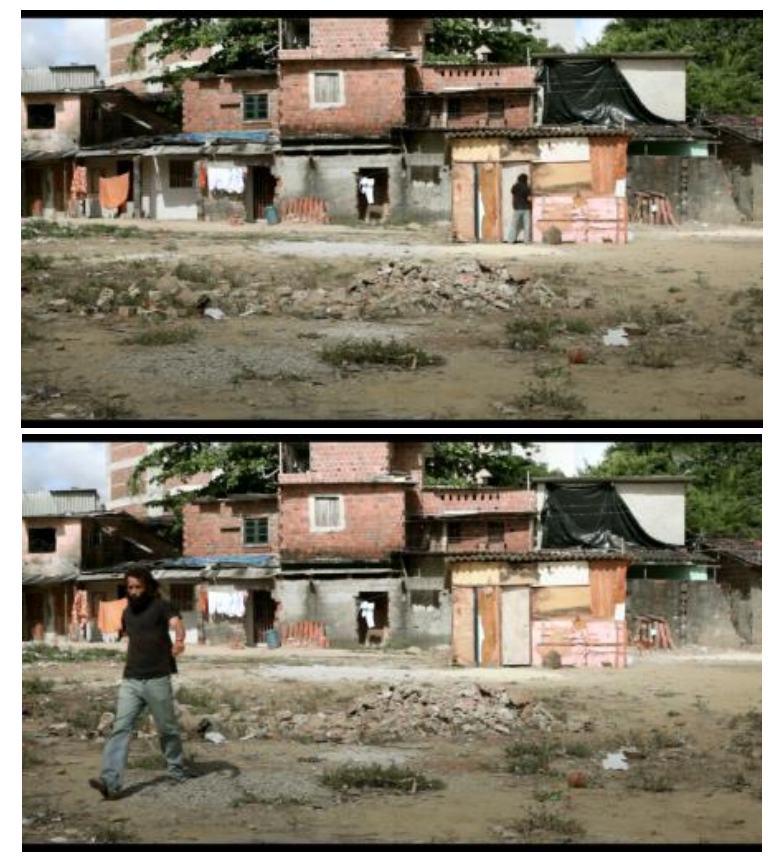




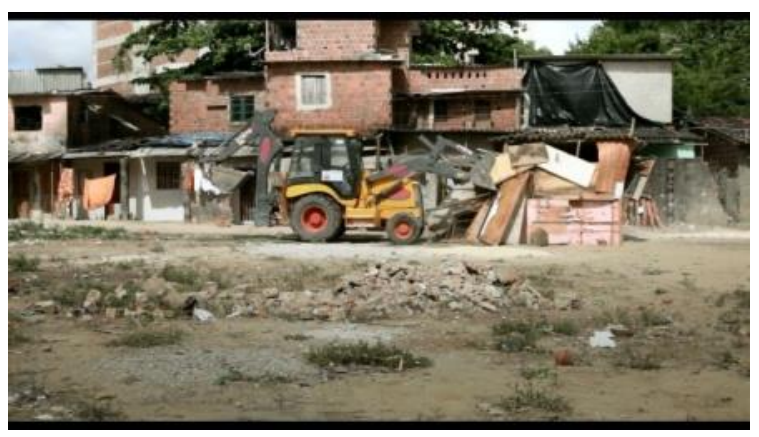

Figura 5

O personagem principal de Em Trânsito é um sujeito que, por um momento, observa a reestruturação do espaço urbano e, em seguida, vê-se seduzido pelo aspecto do poder político relacionado às questões que movem esse mesmo processo urbano. São várias as cenas que possibilitam a criação de um discurso fílmico sobre a questão do espaço urbano, e que fogem, também, do retrato da verticalização da cidade. Como já dissemos, duas variantes são participantes para a reestruturação do espaço urbano: a especulação imobiliária e o setor automobilístico. A imagem atribuída a um sujeito político de importante status simbólico chama a atenção do personagem que termina assim por se entregar ao domínio dos setores que são geradores dos problemas sociais, inclusive da gentrificação e da problemática da mobilidade urbana (Figura 6).

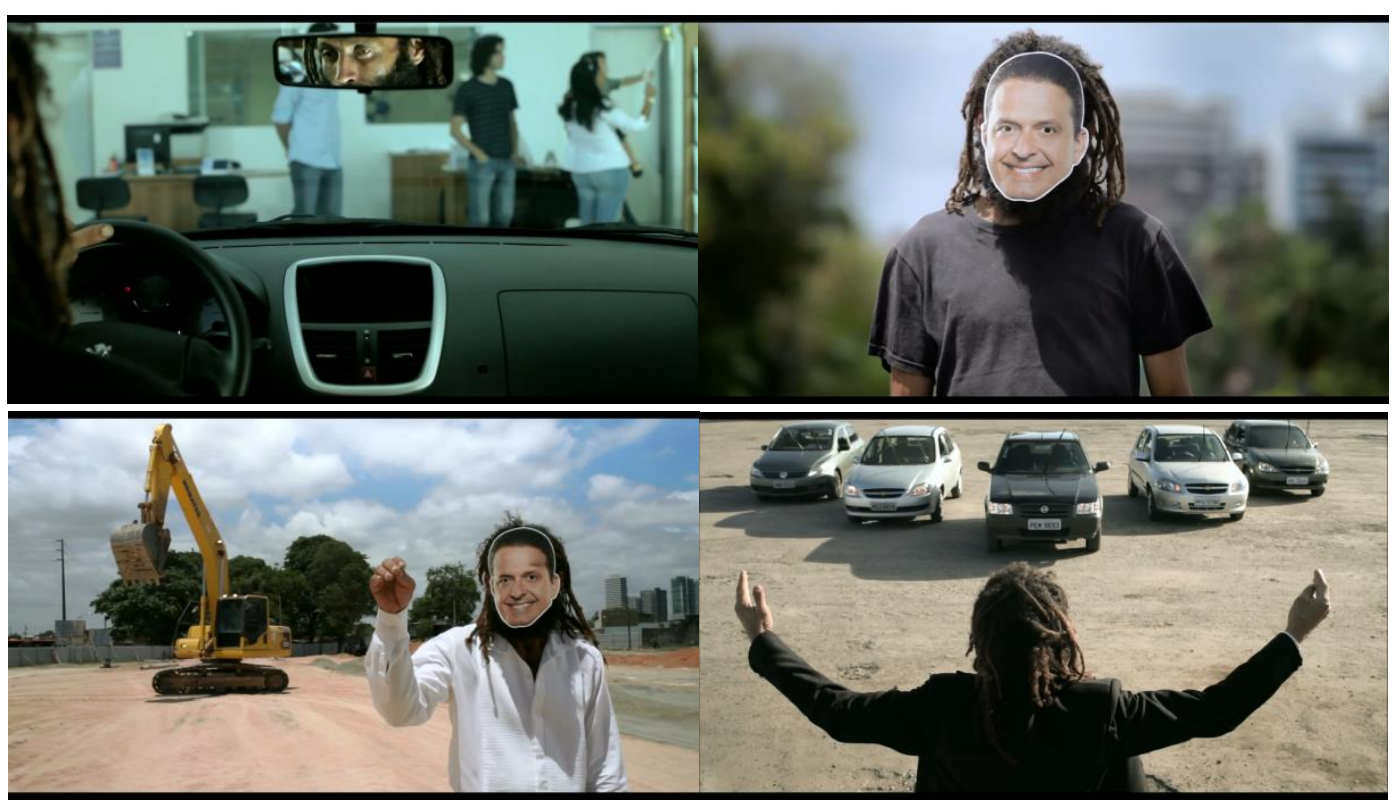

Figura 6 
A sinfonia política da cidade na narrativa do filme comprova a sensibilidade na elaboração poética das questões urbanas do Recife. Tratar um tema utilizando elementos oriundos da própria realidade social, como o jogo político, e elencando as demais partituras de igual relevância para entender o fenômeno urbano do qual estamos falando requer articular sentidos e olhares da cidade, dar destaque a uma profusão de sentidos em razão de outros; recortar um olhar dentre tantos olhares sobre a cidade. É um trabalho verdadeiramente de maestro, uma sinfonia fílmica. Em Trânsito propõe uma análise dessas relações entre os sentidos e os olhares que se podem ter do Recife; ele dá ênfase a um recorte para poder, enfim, imanar em outros debates.

\section{Claves nos lugares da cidade}

A Clave dos Pregões apresenta uma cidade pernambucana sonorizada pelas atividades das pessoas. Trabalhadores transitam pelas ruas e provocam - assim com também participam da construção - a modificação da paisagem sonora dos lugares, visados ou não pela especulação imobiliária. É provocante, neste curta-metragem, a significação do espaço urbano e da transgressão da manutenção da paisagem sonora em determinados trajetos e lugares da cidade. Com efeito, tem-se um plano dicotômico do Recife: de um lado, lugares que mantêm as especificidades das atividades dos trabalhadores de rua, que evocam em alto som os seus produtos, e do outro, lugares que não são vivenciados por essas negociações sociais e contratuais. Logo, em A Clave dos Pregões, a paisagem sonora dos lugares são desdobramentos das paisagens sociais quando entra neste contexto o capital econômico e simbólico das relações sociais.

No plano geral, A Clave dos Pregões constrói uma cidade dividida entre duas paisagens: uma paisagem sonora e uma paisagem social. Ambas as paisagens congregam elementos que são constituintes da formação societal do Recife, inclusive as grandes diferenças econômicas entre as classes sociais. A paisagem sonora é um substrato das configurações das paisagens sociais, pois a sonoridade - inclui os discursos e as falas das pessoas, os sons naturais e os sons produzidos pelo espaço da metrópole - é advinda de uma justaposição de vários ruídos e sons que representam a dicotomia da cidade. 
Esta dicotomia está presente na construção do espaço urbano da cidade do Recife representada neste filme. Assim como pôde ser observado nos outros filmes discutidos neste trabalho, a diferenciação dos lugares através da perpetuação de uma relação de poder está ligada às paisagens simbólicas em que se processam as relações sociais entre as pessoas. Os processos de comunicação e as sociabilidades encontram narrativas diferenciadas nos lugares da cidade, e a dicotomia é gerada, sobretudo, pela configuração de se relacionar com as outras pessoas na ordem da esfera urbana.

Neste curta-metragem, três protagonistas figuram como dispositivos de significação dos espaços por onde transitam/passeiam nos bairros, de classes baixa e média, na cidade do Recife (Figura 7). Tem-se também, na fotografia do filme, a projeção do contraste arquitetônico da estruturação do espaço urbano: em alguns momentos, podem ser vistos prédios altos que fecham a cidade em si mesma, aparecendo como muralhas. As claves nos bairros geram sonoridades nos espaços. As três pessoas que vendem seus produtos são agentes de significação do espaço urbano em que circulam: o "Caldinho da Pink", "a dona do Tamborete" e o casal vendedor de macaxeira.

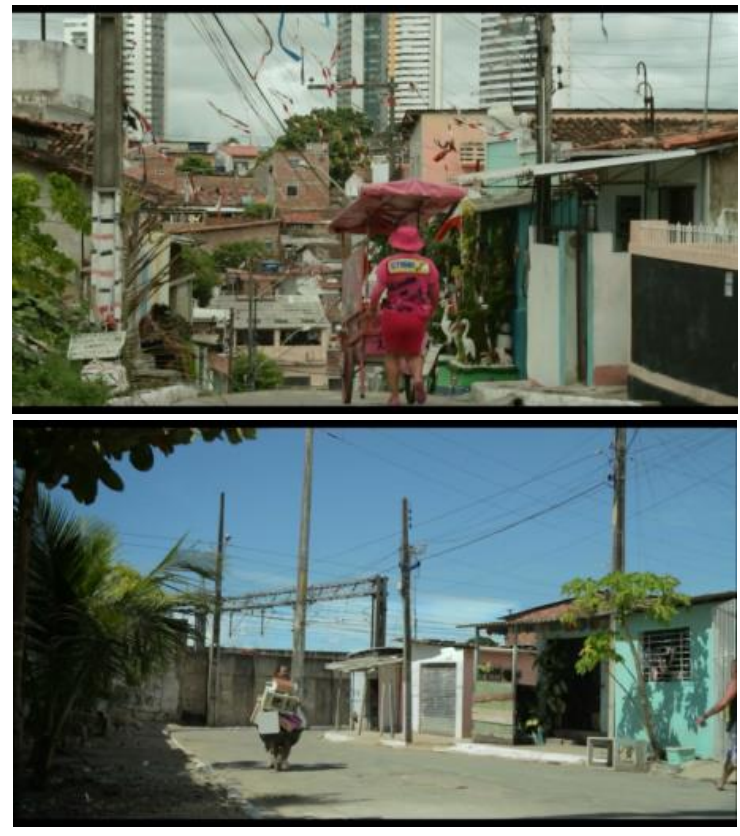




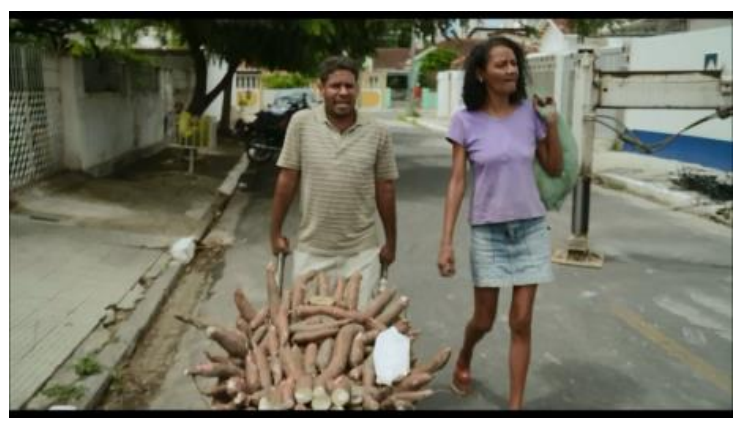

Figura 7

A vendedora "Caldinho da Pink" é uma figura que destoa do ambiente da cidade; ela dá um efeito particular aos espaços por onde circula com o seu carrinho de caldos. Não apenas a sua roupa de trabalho pink - que contribui para criar o personagem "Caldinho da Pink" - chama atenção da população, mas o dispositivo utilizado do microfone que aumenta o alcance da sua voz. Pode-se perceber, em certos momentos do filme, o entrecruzamento desta personagem com os vendedores de macaxeira, apresentando o espaço urbano como um ambiente de encontros e circulação de representações sociais.

"A dona do tamborete" é mais uma protagonista que investe na força da fala para a venda do seu produto. Particularmente, esta vendedora representa na venda do tamborete, um costume que ainda está presente nas cidades de interior dos estados, que é "sentar na frente de casa e falar da vida alheia". Contudo, o costume ainda não se perdeu em Recife, que apesar da extensa verticalização, preserva códigos de comunicação em alguns bairros. A própria vendedora do tamborete dá ênfase à função culturalmente reconhecida do produto. Ou seja, é recorrente no discurso social e no imaginário de uma parte da população, o mantimento de uma ordem do encontro, encontrar, interagir, "falar da vida alheia".

No exemplo do casal vendedor de macaxeira, ele passeia pelas ruas dos bairros, de classes média e baixa. A clave é de apropriar um costume de alimentar-se de macaxeira e os diversos usos que a raiz oferece às pessoas. No aspecto do passeio do casal, os lugares instigam códigos específicos. A paisagem sonora às vezes é muito ruído, outras vezes de silêncio e de "respeito" ao lugar. Esta dicotomia refere-se a espaços considerados do subúrbio da cidade, bairros de moradia da classe trabalhadora, enquanto que os outros são elitizados, da classe dominante. Logo, o conceito de lugar também incorpora as relações de poder e de capital econômico na estrutura social das 
classes sociais corporificado no tipo de residência em que se mora - uma casa num bairro de classe baixa, ou num apartamento de luxo num bairro de alto padrão da classe média ou alta.

Assim, A Clave dos Pregões coloca que os trabalhos ligados às configurações espaciais de um lugar regido ainda por lógicas de comunicação e de negociação diretas, de interação, coexistem no contexto das relações sociais verticalizadas produzidas pelas maneiras de conviver com os outros. As claves dos vendedores transgridem o espaço dos bairros, ultrapassa os muros das casas que "protegem" as pessoas.

Neste filme, a dicotomia de uma cidade que se divide no contexto das relações sociais entre as pessoas, é muito presente nas formas pelas quais a reestruturação do espaço urbano admite proporcionalidades com a interação social. As narrativas urbanas representam realidades sociais, que na conjuntura dos desafios contemporâneos, incidem sobre as comunicações nas cidades. A Clave dos Pregões, na representação das dicotomias entre paisagens sonoras e sociais, arquiteturas do lar e da casa, revela a necessidade de se questionar os sentidos de viver na cidade a partir do sentido que o lugar representa num determinado contexto social (Figura 8).

$\mathrm{O}$ entendimento do habitar liga-se à noção de arquitetura da cidade e dos espaços de relacionamento entre as pessoas. Sentar-se em frente de casa no tamborete e "falar da vida alheia" não é o mesmo de se relacionar com as pessoas na área de convivência num complexo residencial de classe média e alta. As configurações de relacionamento e de comunicação são outras. Nos espaços comuns da cidade, a ordem é de interação, com pessoas que queiram ou não se encontrar e se comunicar. Nesta lógica, os códigos de comunicação são forçados e exigidos a admitir ressignificações no processo de interação social. 


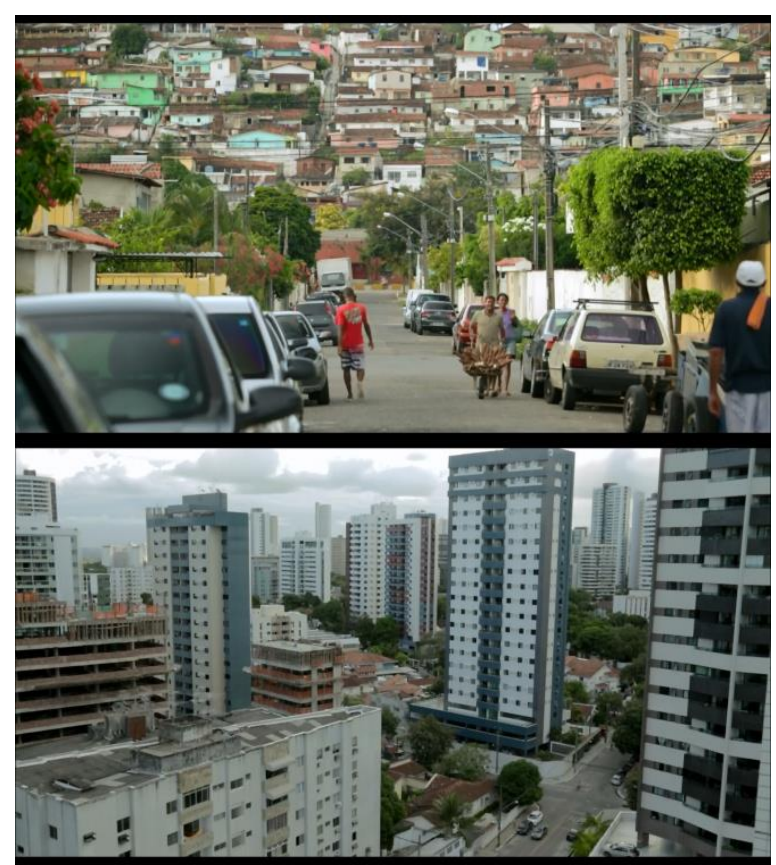

Figura 8

É a partir destes códigos de comunicação que o sentido do lugar é construído. A Clave dos Pregões, assim, é um filme que discute estas configurações que constam no modo de estar e perceber os lugares das cidades, quando se apresenta a potencialidade da paisagem sonora desses espaços em dar sentido aos processos pelos quais passam as relações sociais no âmbito da reestruturação do espaço urbano do Recife.

\section{Considerações finais...}

A cinematografia pernambucana tem indicado a existência de uma produção engajada no discurso sobre o espaço urbano da cidade do Recife. Estes filmes utilizamse dos próprios elementos que fazem parte da construção do espaço urbano da cidade: o imaginário urbano, a memória e a identidade cultural para construir suas narrativas. Algumas produções de curtas-metragens recifenses, especificadamente, são filmes que, a partir da linguagem cinematográfica, organizam um discurso fílmico sobre a questão urbana, porque parte das pessoas que fazem cinema de autor, e de "brodagem", estão envolvidos com grupos de resistência à transformação e reestruturação do espaço urbano, como é o caso dos cineastas que fazem parte do movimento \#OcupeEstelita. 
Problematizar a questão urbana, através da linguagem cinematográfica, possibilita identificar o problema social por meio de diferentes vertentes. Em outras palavras, o cinema funciona como um dispositivo através do qual os olhares sobre Recife ganham desenhos sociais, artísticos e simbólicos. Neste trabalho indicamos três olhares sobre a cidade: a memória, a narrativa política e a dicotomia. Cada uma dessas perspectivas influencia o imaginário urbano da cidade, porque são elaborados segundo os elementos participantes da construção do espaço urbano.

A memória da cidade no aspecto do fluxo do tempo nas fotografias feitas por Alcir, retrato no curta-metragem Pausas Silenciosas, defende a concepção de mudança não apenas na semântica urbana do espaço urbano, como também das configurações das convivências entre as pessoas. As fotografias são, neste filme, dispositivos adotados para rememorar uma cidade que não existe mais, que existe somente nas imagens, e na memória das pessoas que viveram nela, em um tempo que as relações sociais continham outras singularidades. A narrativa do espaço urbano articula-se aos sentidos das fotografias de Alcir, no quesito do espaço-tempo, revelando as diferenças entre as ruas, avenidas, lugares e espaços do Recife antigo ao Recife atual.

A narrativa política da cidade no curta-metragem Em Trânsito destaca um ponto central da reestruturação do espaço urbano: a luta de classes sociais e o jogo político oriundo das relações entre eleitor e candidato. A narrativa orgânica neste filme preocupa-se em representar uma cidade apartada, aonde os projetos arquitetônicos, culturais e econômicos da especulação imobiliária e do setor automobilístico atentam para a classe média e alta do Recife. Portanto, ocorre o processo da gentrificação, uma conseqüência social destes projetos políticos que enquadram um modo de vida urbano regido por lógicas liberais, tendo o capital econômico e simbólico da aquisição do automóvel e dos caros apartamentos como objetos de significância social e identitária.

A dicotomia da cidade no curta-metragem A Clave dos Pregões relaciona a paisagem sonora, a arquitetura urbana e os sentidos dos lugares da cidade na ocorrência dos contrates urbanos e, principalmente sociais. Com efeito, os passeios dos personagens por ruas e avenidas, e em lugares de significação simbólica, congregam valores a estes espaços e representam as sonoridades como elementos definidores do poder contido nos lugares de moradia das classes baixa e média. As claves e as comunicações e contratos entre as pessoas na ordem urbana se dão, na conjuntura do poder e do simbólico dos lugares, de outras formas, como apresentado pelo filme. 
As divergências, incongruências, contrastes, singularidades da cidade do Recife representadas nos curtas-metragens contemporâneos Pausas Silenciosas, Em Trânsito e A Clave dos Pregões foram analisados por meio do discurso social e fílmico partindo dos princípios da Antropologia Urbana, que identifica a potencialidade simbólica dos lugares e das interações diretas entre as pessoas, e do Cinema, na participação do gênero documentário que situa perspectivas acerca de um problema de relevância social.

Os curtas-metragens pernambucanos analisados neste trabalho são importantes para entender os processos existentes no contexto espacial e social. As dinâmicas sociais da cidade, como discutido neste trabalho, podem ser visitadas na memória, na identidade e no discurso sobre Recife. Foi esse o aspecto central do estudo: analisar os olhares fílmicos sobre a cidade do Recife e delimitar a questão urbana dos discursos fílmicos dos curtas-metragens contemporâneos pernambucanos.

\section{Referências}

ALVES, A. SAMAIN, E. Os argonautas do mangue precedido de Balinese character (re)visitado. Campinas: Editora Unicamp/São Paulo: Imprensa Oficial do Estado de São Paulo, 2004.

AMÂNCIO, T. O Brasil dos Gringos: Imagens no Cinema. Niterói: Intertexto, 2000.

AUGÉ, M. Não-Lugares - Introdução a uma Antropologia da Supermodernidade. Campinas: Papirus Editora, 2008.

BARBER, S. Projected Cities: Cinema and Urban Space. Londres: Reaktion Books Ltd, 2002.

BARBOSA, A. CUNHA, E. T. Antropologia e imagem. Ciências Sociais - Passo a Passo 68 - Editor Jorge Zahar, 2006.

BAUMAN, Z. Confiança e medo na cidade. Rio de Janeiro: Jorge Zahar Ed., 2009.

BORDWELL, D. "Camera Movement and Cinematic Space". In: BURNETT, R. (Ed.). Explorations in Film Theory - Selected Essays From Cine-Tracts. Bloomington: Indiana University Press, 1991.

BOURDIEU, P. O poder simbólico. Trad. Fernando Tomaz. Rio de Janeiro: Bertrand Brasil, 2002.

A economia das trocas simbólicas. São Paulo: Perspectiva, 2007.

BRUNO, G. Atlas of Emotion: Journeys in Art, Architecture and Film. New York: Verso, 2002.

CALDEIRA, T. P. Cidade de Muros: Crime, Segregação e Cidadania em São Paulo. São Paulo: Editora 34/Edusp, 2000.

CAMPO, J. Cine documental: tratamiento creativo (y político) de la realidad. Cine Documental, n. 11, pp. $01-28,2015$.

CANEVACCI, M. A cidade polifônica: ensaio sobre a antropologia da comunicação urbana. São Paulo: Studio Nobel, 2004.

COMOLLI, J-L. Ver e poder. Belo Horizonte: Editora UFMG, 2008. 
COSTA, M. H. B. e V. Ficção \& Documentário: Hibridismo no Cinema Brasileiro Contemporâneo. O Percevejo Online - Periódico do Programa de Pós-Graduação em Artes Cênicas PPGAC/UNIRIO, n. 02, vol. 05, pp. 165 - 190, 2014. Disponível em: http://www.seer.unirio.br/index.php/opercevejoonline/article/viewFile/3777/pdf_1317 Acesso em 02 de junho de 2014.

COSTA, W. M. A. "Documentário pernambucano de curta-metragem: espacialidades e narrativas nos filmes Câmara Escura e A Clave dos Pregões”. In: RENÓ, D. P. [et al.] 1a ed. Ficção e documentário: memória e transformação social. Rosario: UNR Editora. Editorial de la Universidad Nacional de Rosario, 2016a, pp. 367-378.

Memórias e narrativas híbridas no cinema brasileiro contemporâneo. In: XI Seminário de Pesquisa em Ciências Humanas, Curitiba. Anais eletrônicos... São Paulo: Editora Edgard Blucher, 2016b. Disponível em: < http://www.proceedings.blucher.com.br/article-details/memrias-e-narrativas-hbridas-nocinema-brasileiro-contemporneo-23672> Acesso em 04 de janeiro de 2017.

DE CERTEAU, M. A invenção do cotidiano: artes de fazer. Petrópolis: Editora Vozes, 1998.

GAUTHIER, G. El documental narrativo. Documental/ficción. Revista On-Line Cine Documental, n. 7, primer semestre, pp. $01-14,2013$.

GOMES, P. C. C. O lugar do olhar: elementos para uma geografia da visibilidade. Rio de Janeiro: Bertrand Brasil, 2013.

JAMESON, F. Espaço e imagem: teorias do pós-moderno e outros ensaios de Fredric Jameson. Rio de Janeiro: Editora UFRJ, 2004.

LIPOVETSKY, G. A estetização do mundo: viver na era do capitalismo artista. São Paulo: Companhia das Letras, 2015.

LYNCH, K. A imagem da cidade. Rio de Janeiro: Edições 70, 1960.

MAGNANI, J. G. C. "Quando o campo é a cidade: fazendo Antropologia na metrópole". In: , e TORRES, L. L. (Orgs.). Na Metrópole: textos de Antropologia Urbana. São Paulo: EDUSP, 2008, pp. 12 - 52.

. De perto e de dentro: notas para uma etnografia urbana. Revista Brasileira de Ciências Sociais, vol. 17, n. 49, jun/2002.

NEVES, A. A. Geografias de Cinema: do espaço geográfico ao espaço fílmico. EntreLugar, Dourados, MS, ano 1, n. 1, pp. $133-156,1^{\circ}$ semestre, 2010.

NOGUEIRA, A. M. C. O Novo Ciclo de Cinema em Pernambuco: A questão do estilo. Recife: Editora Universitária UFPE, 2009.

ORTEGA, V. R. "Identificando o conceito de cinema transnacional". In: FRANÇA, A., LOPES, D. (Orgs.). Cinema, globalização e interculturalidade. Santa Catarina: Argos, 2010, pp. $67-90$.

SHOTAT, E. STAM, R. Crítica da Imagem Eurocêntrica: multiculturalismo e representação. São Paulo: Cosac e Naify, 2006.

VALLEJO, A. V. Narrativas documentales contemporâneas. De la mostración a la enunciación. Cine Documental, n. 7, pp. 03 - 29, 2013.

VALLES, R. R. Las fronteras de la percepción en la imagen cinematográfica. Un análisis sobre la construcción de lo real en el cine documental. Cine Documental, n. 11, pp. $52-74,2015$.

VELHO, G. Um antropólogo na cidade: ensaios de antropologia urbana. In: VIANNA, H., KUSCHNIR, K. CASTRO, C. (Orgs.). Rio de Janeiro: Zahar, 2013.

A utopia urbana: um estudo de antropologia social. Rio de Janeiro: Jorge Zahar Ed., 2002.

Individualismo e cultura: notas para uma Antropologia da Sociedade Contemporânea. Rio de Janeiro: Zahar Editores, 1981. 
XAVIER, I. "A teatralidade como vetor do ensaio fílmico no documentário brasileiro contemporâneo". In: TEIXEIRA, F. E. (Org.). O ensaio no cinema: formação de um quarto domínio das imagens na cultura audiovisual contemporânea. São Paulo: Hucitec, 2015, pp. $226-246$.

Recebido em: 20/10/2017. Aprovado em: 15/11/2017. 